\title{
HEART AT RISK: ELECTRONIC EDUCATIONAL GAME WITH INFORMATION ON DOPING IN ATHLETES
}

\author{
CORAÇÃO EM JOGO: JOGO ELETRÔNICO EDUCATIVO NA INFORMAÇÃO DO DOPING EM ATLETAS \\ CORAZÓN EN JUEGO: JUEGO ELECTRÓNICO EDUCATIVO EN LA INFORMACIÓN DEL DOPING EN ATLETAS
}

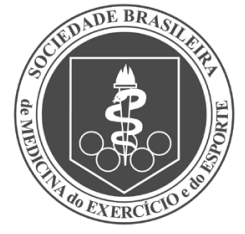

Original Article

Artigo Original Artículo Original
Henrique Custódio da Silva ${ }^{1}$ (Physician)

Êdio Fernandes de Miranda² (Statistician)

Mariseth Carvalho de Andrade (Statistician)

Fernando Mateus Viégas Brandão' (Medical Graduate)

Rodrigo Paracampo Couteiro (Medical Graduate)

Marcus Vinícius Henriques Brito ${ }^{3}$ (Physician)

Julio Cezar Costa Furtado ${ }^{4}$

(Computer Science)

Rafael Oliveira Chaves ${ }^{1,3}$

(Physician and Electrical Engineer)

1. Universidade do Estado do Pará (UEPA), Belém, PA, Brazil.

2. Centro Universitário do Estado do Pará (CESUPA), Belém, PA, Brazil. 3. Universidade Federal do Pará (UFPA), Belém, PA, Brazil.

4. Universidade Federal do Amapá (UNIFAP), Macapá, AP, Brazil.

\section{Correspondence:}

Henrique Custódio da Silva.

Programa de Pós-Graduação

Mestrado Profissional em Cirurgia

e Pesquisa Experimental da

Universidade do Estado do Pará

(UEPA). Br-316, Av. Tropical, 40,

Condomínio Oásis Alameda Sabiá,

Casa 3, Guanabara, Ananindeua,

Pará, PA, Brazil. 67110-040.

custodio@cardiol.br

\begin{abstract}
Introduction: Games are recognized tools that can be used for teaching, awareness-building and behavioral change. In the world of competitive sports, it is necessary to both educate athletes and make them aware that doping is an unsportsmanlike practice, particularly because this conduct can be life-threatening. A game called "Heart at Risk" was developed in this context for the purpose of teaching athletes which substances are characterized as doping by the World Antidoping Agency, and to raise their awareness of health hazards through entertainment. Objective: Present and empirically evaluate the efficacy of the game as a tool for educating athletes on substances characterized as doping. Methods: The sample group was formed by 20 players in the under-20 category of Clube do Remo (Rowing Club), aged over 18 years. The athletes underwent a pre-test, played the Heart at Risk game, and took a post-test at the end. Both tests were related to healthy sport practices (positive factors) and to doping substances (negative factors). Results: Regarding the knowledge of positive factors, there was an increase of knowledge in relation to low doses of caffeine ( $\Delta=40 \%$; $p$-value $=0.0125)$ and doping assessment $(\Delta=55 \%$; $p$-value $=0.0017)$. Regarding negative factors, there was an increase of knowledge in relation to diuretics $(\Delta=$ $25 \%$; $p$-value $=0.0455)$, contaminated thermogenic $(\Delta=35 \%$; $p$-value $=0.0191)$, growth hormone-GH $(\Delta=50 \%$; $p$-value $=0.0025)$, contaminated supplements $(\Delta=65 \% ; p$-value $=0.0007)$, and testosterone $(\Delta=55 \% ; p$-value $=$ 0.0017). Conclusion: The Heart at Risk game proved to be an effective resource in the process of learning about prohibited substances and positive factors for sports performance. Level of Evidence IV; Case series.
\end{abstract}

Keywords: Doping in sports; Games, experimental; Athletes; Education.

\section{RESUMO}

Introdução: Jogos são reconhecidos instrumentos que podem ser usados para ensino, conscientização e mudança de comportamentos. No competitivo mundo esportivo, educar e conscientizar que doping éuma prática antiesportiva são duas necesidades, principalmente porque essa atitude pode colocar a vida do atleta em risco. Nesse contexto, foi desenvolvido um jogo, chamado Coração em Jogo, com o objetivo de ensinar aos atletas quais substâncias são caracterizadas como doping pela World Anti-Doping Agency, eludicamente conscientizá-los dos riscos para a saúde. Objetivo: Apresentar e avaliar empiricamente a eficácia do Coração em Jogo como ferramenta para educação de atletas sobre substâncias caracterizadas como doping. Métodos: A amostra foi formada por 20 jogadores da categoria sub-20 do Clube do Remo, com idade superior a 18 anos. Os atletas realizaram pré-teste ejogaram o Coração em Jogo, e, ao término, foi aplicado um pós-teste. Ambos os testes eram relativos a práticas esportivas saudáveis (fatores positivos) e sobre substâncias dopantes (fatores negativos). Resultados: Em relação ao conhecimento de fatores positivos, houve aumento do conhecimento em baixas doses de cafeína ( $\Delta=40 \%$; valor de $p=0,0125)$ e avaliação de dopagem $(\Delta=55 \%$; valor de $p=0,0017)$. Em relação aos fatores negativos, ocorreu aumento do conhecimento em diuréticos $(\Delta=25 \%$; valor de $p=0,0455)$, termogênico contaminado $(\Delta=35 \%$; valor de $p=0,0191)$, hormônio do crescimento $(\Delta=50 \%$; valor de $p=0,0025)$, suplementos contaminados $(\Delta=65 \%$; valor de $p=0,0007)$ e testosterona $(\Delta=55 \%$; valor de $p=0,0017)$. Conclusão: O Coração em Jogo mostrou-se recurso eficaz na aprendizagem das substâncias proibidas e dos fatores positivos para desempenho do esporte. Nível de Evidência IV; Série de casos.

Descritores: Doping nos esportes; Jogos experimentais; Atletas; Educação.

\section{RESUMEN}

Introducción: Los juegos son reconocidos instrumentos que pueden ser usados para enseñanza, concientización y cambio de comportamientos. En el competitivo mundo deportivo, educar y concientizar que doping es una práctica antideportiva son dos necesidades, principalmente porque esa actitud puede poner la vida del atleta en riesgo. En este contexto se desarrolló un juego llamado "Corazón en juego (Coração em Jogo en su nombreen portugués),"con el objetivo de enseñar a los atletas qué sustancias son caracterizadas como doping por la World Antidoping Agency, y lúdicamente concientizarse de los riesgos para su salud. Objetivo: Presentary evaluar empíricamente la eficacia de "Corazón en Juego", como una herramienta para la educación de atletas sobre sustancias que se caracterizan como doping. Métodos: La muestra fue formada por 20 jugadores de la categoría sub-20 del Club del Remo, con edad superior a 18 años. Los atletas realizaron test previo y jugaron "Corazón en Juego", y al término se aplicó un test posterior. Ambos tests se referían a prácticas deportivas saludables (factores positivos) y sobre sustancias dopantes (factores negativos). Resultados: Con relación al conocimiento de factores positivos, hubo aumento del conocimiento en bajas dosis de cafeína $(\Delta=40 \%$, valor de 
$p=0,0125)$ y evaluación de dopaje ( $\Delta=55 \%$; valor de $p=0,0017)$. Con relación a los factores negativos, ocurrió a umento del conocimiento en diuréticos $(\Delta=25 \%$, valor de $p=0,0455)$, termogénico contaminado $(\Delta=35 \%$, valor de $p=0,0191)$, hormona del crecimiento $(\Delta=50 \%$, valor de $p=0,0025)$, suplementos contaminados $(\Delta=65 \%$, valor de $p=0,0007)$ y testosterona ( $\Delta=55 \%$, valor de $p=0,0017)$. Conclusión: "Corazón en Juego," se mostró un recurso eficaz en el aprendizaje de las sustancias prohibidas y de los factores positivos para desempeño del deporte. Nivel de evidencia IV; Serie de casos.

\section{Descriptores: Doping en los deportes; Juegos experimentales; Atletas; Educación.}

\section{INTRODUCTION}

For the World anti-doping Agency (WADA), doping is defined as the occurrence of one or more violations of its anti-doping regulation. The list is wide and covers from the presence of prohibited substances or methods in the athlete's samples (e.g. blood and urine), through refusal or non-delivery of samples for analysis, reaching to attempts of tamper or falsification of any part at the doping control. ${ }^{1}$ In addition, WADA establishes that it is the sole responsibility and duty of the athlete to ensure that any prohibited substance is in your body and no marker or substance is found in any sample extracted from your body.

WADA $^{1}$ also stipulates that for a substance or method be considered doping, it must fulfill at least 2 of the following three criteria: (1) Medical or scientific evidence that the substance or the whole has an effect capable of - alone or in combination with other substances or methods - increasing or improving sports performance; (2) Medical evidence or scientific proof that the use of the substance or method represent a real or potential risk to the athlete's health; (3) The use of the substance or method violates the sport spirit described in the code of WADA. ${ }^{1}$

The awareness against doping has been the concern, in Brazil we can mention the Brazilian Authority of Control of Doping ${ }^{2}(A B C D)$, that widespread information, education, prevention, intelligence and action. It is affirmed in its regulation that doping does not only cause adverse effects, but also are harmful substances to the health of athletes, besides the impact on the economy costing very high to combat this practice, reaching nearyly 300 million dollars per year worldwide. ${ }^{3}$

A viable option for doping education is the use of electronic games as facilitators of learning by presenting inherent features such as: the ability to awaken interest and motivation in a broad audience, the ability to retain (keeping players for long periods engaged in the activity) and the versatility to adapt to almost all subjects. ${ }^{4,5}$ These games are not merely about entertainment, but the learning of specific subjects through the application of theoretical content to real or almost real situations. They allow the player to interact, reflect, acquire and consolidate the knowledge, in a practical and active way. ${ }^{6}$

In this context we can mention serious games that have as its main objective the education in diverse areas of knowledge, whether it is health, public politics and communication, ${ }^{6}$ as Escape from Diab and the Nanoswarm: Invasion from Inner Space, games developed for prevention of child obesity, and the DECIDIX, directed to promote sexual and reproductive health of teenagers. ${ }^{8}$ Another approach used an electronic game to address the theme of food and nutrition education with children from 7 to 10 years. ${ }^{9}$

There are some reasons why electronic games can be an excellent tool for learning: (1) offer a suitable environment that allows the player to enjoy a wide experimentation and visualize the consequences of their acts, thus learning from their own mistakes; (2) allow the player to learn by doing, decreasing the separation between theory and practice; (3) offer instant and customized feedback to each player and; (4) facilitate the player's imersion in the learning process more easily. ${ }^{10-12}$
Having the need to educate and raise awareness about anti-doping, and the electronic games being an important instrument to support teaching, this paper presents an electronic game, named Heart in Game, with the aim of teaching athletes about substances that are defined doping according to WADA. ${ }^{1}$

\section{METHODS}

The study was characterized by being the type quasi-experimental ${ }^{13}$ and descriptive. In cases of samples for convenience of pre-formed group in a specific population.

The development of the game took 3 stages of modeling: $1^{\text {st. }}$ plot, scenery, stages of the game, mechanics; $2^{\text {nd. }}$ control of the character, creation of objects, movement on the track; $3^{\text {rd: }}$ creation of the menu, point accounting, interaction with objects and instruction to users.

The competences to be developed in the game are: (1) Recognize the possible scenarios of finding negative and positive factors in the sport practice; (2) Identify the positive factors that can promote sports performance in real life; (3) To categorize the negative factors, the substances prohibited by doping committees.

The game has 3D scenarios in pixel style, with basic commands to move forward, backward, right and left. The game mode was divided into 3 stages with missions for each one, with progressive difficulty to the success of each stage. It presents the maximum time of entire realization of 6 minutes, empirically defined by the researchers prior to the experiment. Have a pre-existing character is available in a single player mode (Figure 1).

The game has three stages, each of them occuring in a virtual environment that represent the following real-world environments: (1) a pharmacy; (2) a supermarket and; (3) a gym. The mission to be accomplished is presented at the beginning of each stage (Figure 2). A mission is basically composed of two lists of items, one with those considered positive factors and another with those that are considered negative factors (considered doping by WADA ${ }^{1}$ ). Each item presented in a stage is typically found in its respective real-world environment. During the match, the player will have to collect a specific number of each item of positive factors and avoid as much as possible to collect items of negative factors, and should turn away from these, at a maximum preset time at the beginning of each stage. For each item of positive factors collected, a positive score will be attributed to the player, and to each negative factor collected, a score greater than that attributed to the positive factors will be withdrawn, and the end of the game may occur before completing the stage mission. The realization of the stage in less time generates bonus for each second unless that established as maximum, generating a score that will be recorded in the game menu if it is a record.

\section{Study sample}

Twenty soccer players in the under-20 category of Clube do Remo, a federated team drawn among the teams of the Soccer Federation of Pará, were participants, aged between 18 and 20 years.

A questionnaire was elaborated by the authors to quantify the correct answers in the variables related to substances prohibited by WADA 


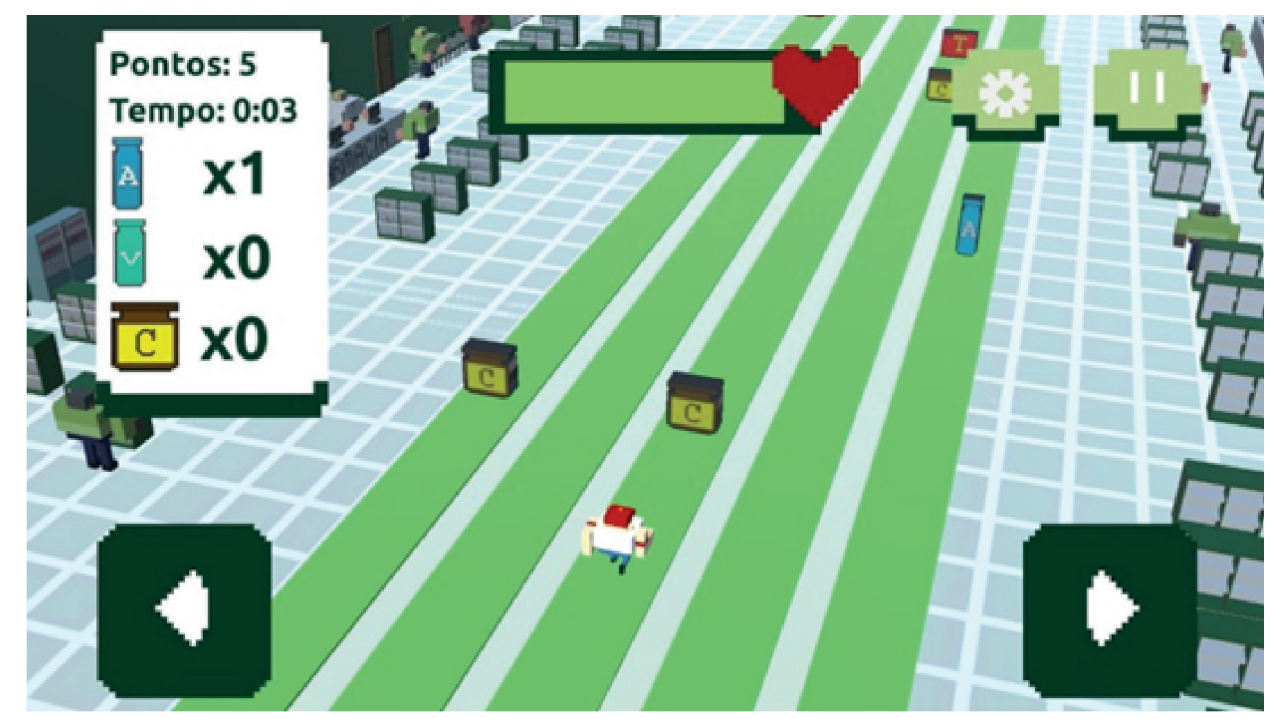

Source: Search protocol, game "Heart in Game".

Figure 1. Player in the gym phase collecting positive items.

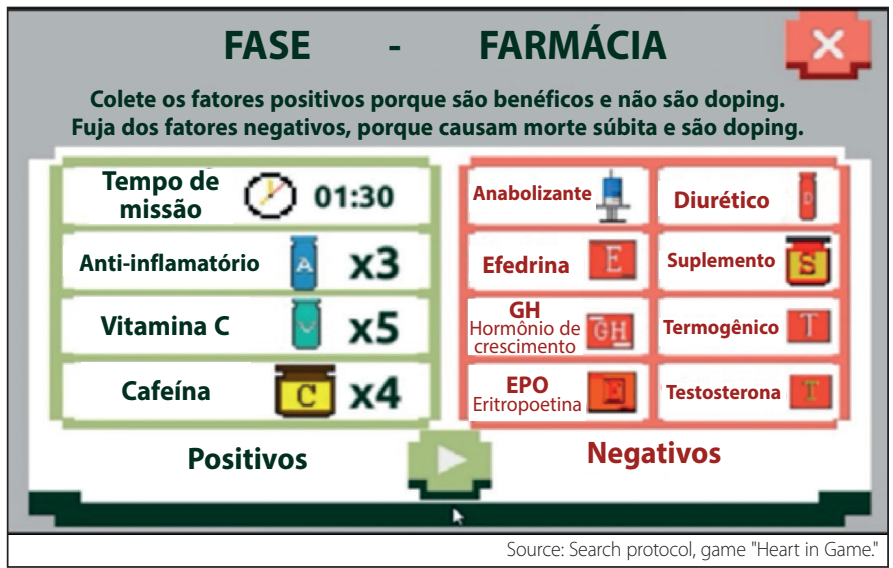

Figure 2. List of positive and negative factors the player must collect and avoid, respectively, during the pharmacy phase.

and favorable to the sportsman. Before starting the tests, all participants agreed to participate in the study by signing Informed Consent Form. The application happened in two moments: before the game to measure the previous knowledge and, immediately after the game, to verify the effectiveness of the game in learning. The time limit of the survey was 15 minutes, not allowing interaction between athletes and use of means of consultation during the research. The following aspects were defined in the question:

- Positive factors: Non-steroidal anti-inflammatory, low dose of caffeine, vitamin C, doping, fruit, physical exercise and water.

- Negative factors: erythropoietin, diuretics, ephedrine (>10mcg), contaminated thermogenic, growth hormone $(\mathrm{GH})$, anabolic steroids, contaminated supplementation, cocaine, testosterone and cannabis.

The application of the game and data collection was carried out at the computer lab of the Center for Biological Sciences and Health, campus II of the State University of Pará. The intervention took place on February 22 for all 20 participants.

Firstly, the athletes invited to participate in the research took the doubts and signed the TCLE, agreeing to participate in the study. Subsequently, the participants received basic instructions on the game and how the experiment would occur. Then, the players received the questionnaire containing two lists, each presented 20 items classified as positive factors and 20 classified as negative factors and considered doping, according to WADA. ' Within the items, there were options of confusion for marking, items that do not fit the positive and negative factors. The athletes marked based on their previous knowledge about the positive and negative factors. After answering and delivering the questionnaire, the athletes played the three stages of the game. When completing the 3 stages of the game, participants had to redo the same questionnaire with the knowledge they obtained in the dynamics of the game. At the end of the experiment, the players had knowledge of their performances in the pre and post tests.

The study was approved by the Research Ethics Committee of University of the State of Pará (CEP-UEPA) through the protocol number 2,346,069. The data were collected only after the approval of the research by the CEP-UEPA, obeying the ethical precepts of the Declaration of Helsinki and the Code of Nuremberg and the regulatory norms for research with human beings of resolution 466/12 of the National Health Council.

\section{Statistical analysis}

To verify the normality of the values obtained in the research, the Shapiro-Wilk test was applied, where they did not obey the normal distribution, requiring a non-parametric test. To evaluate the results of the group of players before and after the electronic game, the Wilcoxon test was calculated. Descriptive and analytical statistics were performed in the Bioes-Tat ${ }^{\circledR} 5.3$ software. Significance level $a=0.05$ or $5 \%$ was adopted.

\section{RESULTS}

Regarding the gain of knowledge on the positive factors for sports practice, see Table 1, the pre and post-game moments, it can be observed that the greatest highlights were in relation to the low caffeine dose and the doping evaluation, where there was an increase of $\Delta=40 \%$ ( $p$-value $=$ $0.0125)$ and $\Delta=55 \%$ ( $p$-value $=0.0017$ ), respectively, in the percentage of correct answers after the game. The positive factors: fruits ( $p$-value $=$ DNA $\left.{ }^{*}\right)$, physical exercise $(p$-value $=0.1587)$, water $\left(p\right.$-value $\left.=D N A^{*}\right)$, anti-inflammatory drugs $\left(p\right.$-value $\left.=D N A^{*}\right)$ and vitamin $C(p$-value $=$ 0.1587) did not have statistical difference between the correct answers in the two evaluation moments.

Regarding the gain of knowledge on negative factors to sports practice, comparatively at pre and post-game moments, according to Table 2, we can observe that the greatest highlights were in relation to 
Table 1. Evaluation of pre-and post-game knowledge gain, in number of correct answers on positive factors to physical activity practices by athletes of the under-20 category of Clube do Remo, March 2018.

\begin{tabular}{c|c|c|c|c|c}
\hline Positive factors & \multicolumn{2}{|c|}{ Pre game hits } & \multicolumn{2}{c|}{ Post game hits } & p - value \\
\hline $\begin{array}{c}\text { Non-steroidal anti- } \\
\text { inflammatory }\end{array}$ & 8 & $40.0 \%$ & 8 & $40.0 \%$ & DNA $^{*}$ \\
\hline Low dose of caffeine & 6 & $30.0 \%$ & 14 & $70.0 \%$ & 0.0125 \\
\hline Doping & 4 & $20.0 \%$ & 15 & $75.0 \%$ & 0.0017 \\
\hline Vitamine C & 19 & $95.0 \%$ & 18 & $90.0 \%$ & 0.1587 \\
\hline Fruit & 20 & $100.0 \%$ & 20 & $100.0 \%$ & DNA $^{*}$ \\
\hline Physical Exercise & 19 & $95.0 \%$ & 20 & $100.0 \%$ & 0.1587 \\
\hline Water & 20 & $100.0 \%$ & 20 & $100.0 \%$ & DNA $^{*}$ \\
\hline Overall average of hits & 16.0 & $80.0 \%$ & 19.0 & $95.0 \%$ & 0.0001 \\
\hline
\end{tabular}

Test Wilcoxon; *DNA-does not apply; Source: Search Protocol.

Table 2. Evaluation of pre-and post-game knowledge gain, in number of correct answers on the main negative factors to physical activity practices by athletes of the under-20 category of Clube do Remo, March 2018.

\begin{tabular}{c|c|c|c|c|c}
\hline Negative factors & \multicolumn{2}{|c|}{ Pre game hits } & \multicolumn{2}{c}{ Post game hits } & p - value \\
\hline Erythropoietin & 4 & $20.0 \%$ & 7 & $45.0 \%$ & 0.1130 \\
\hline Diuretics & 5 & $25.0 \%$ & 10 & $50.0 \%$ & 0.0455 \\
\hline Ephedrine (>10mcg) & 10 & $50.0 \%$ & 13 & $65.0 \%$ & 0.1552 \\
\hline $\begin{array}{c}\text { Contaminated } \\
\text { Thermogenic }\end{array}$ & 7 & $35.0 \%$ & 14 & $70.0 \%$ & 0.0191 \\
\hline GH & 4 & $20.0 \%$ & 14 & $70.0 \%$ & 0.0025 \\
\hline Anabolic Steroids & 18 & $90.0 \%$ & 16 & $80.0 \%$ & 0.0899 \\
\hline $\begin{array}{c}\text { Contaminated } \\
\text { Supplementation }\end{array}$ & 3 & $15.0 \%$ & 16 & $80.0 \%$ & 0.0007 \\
\hline Cocaine & 17 & $85.0 \%$ & 17 & $85.0 \%$ & $0 \mathrm{NA}$ \\
\hline Testosterone & 7 & $35.0 \%$ & 18 & $90.0 \%$ & 0.0017 \\
\hline Cannabis & 18 & $90.0 \%$ & 20 & $100.0 \%$ & 0.0899 \\
\hline Overall Average of Hits & 9.3 & $46.5 \%$ & 16.0 & $80.0 \%$ & 0.0001 \\
\hline
\end{tabular}

Test Wilcoxon; *DNA-does not apply; Source: Search Protocol.

diuretics ( $p$-value $=0.0455)$, contaminated thermogenics ( $p$-value $=$ $0.0191), \mathrm{GH}$ ( $p$-value $=0.0025)$, supplements ( $p$-value $=0.0007)$ and testosterone ( $p$-value $=0.0017$ ), which increased $\Delta=25 \%, \Delta=35 \%$, $\Delta=50 \%, \Delta=65 \%$ and $\Delta=55 \%$, respectively, after the experience in the eletronic game. The answers related to erythropoietin ( $p$-value $=0.1130$ ), ephedrine ( $p=$ value $=0.1552$ ), anabolical steroids ( $p$-value $=0.0899)$, cocaine $\left(p\right.$-value $\left.=D N A^{*}\right)$ and cannabis $(p$-value $=0.0899)$ did not showed statistically significant difference between the two evaluation moments.

\section{DISCUSSION}

The evaluation of the efficacy of learning the positive factors shows us that even the athletes already possessing an average of $80 \%$ in the pre-test, the game was able to provide a knowledge gain in the post-test, with a positive variation of $\Delta=15 \%$ ( $p$-value $=0.0001)$.

Positive data could be observed in the gain of knowledge about low doses of caffeine. After the game, in the post teste, an increase of $\Delta=40 \%$ ( $p$-value $=0,0125$ ) occurred. The athletes began to recognize this as a beneficial item for the improvement in physical performance. Caffeine is a substance that is quite controversial and causes doubt about being beneficial, ${ }^{14}$ a hypothesis by which there was no unanimity after the game. By the end of 2003, caffeine was on the list of prohibited substances of WADA, ${ }^{15}$ in the class of stimulants, however, in the list of 2018 the substance is not listed as a prohibited item. ${ }^{1}$

Another positive factor that obtained a gain in the learning was the evaluation of doping control, with $\Delta=55 \%$ ( $p$-value $=0.0017$ ). Preferably performed by a doping control officer, the authority in the doping control, and for this reason should be considered a positive factor for those practicing sports, since it is a fundamental piece to ensure the safety and justice in the competition. ${ }^{2}$

Regarding the evaluation of the efficacy of the game in the learning of the negative factors, it can be observed that after the end of the game, there was significant statistical significance ( $p$-value= 0.0001 ), with an increment of $\Delta=33.5 \%$. It can be affirmed that the electronic game was able to promote knowledge about prohibited substances. The pre-test mean was lower than 50\%, this low level of knowledge about doping is not an exception of the present study, similar results were found when investigating the understanding of Australian athletes about the items on the list of prohibited substances of the WADA. ${ }^{16}$

Although the athletes easily identified that the term anabolic refers to a negative factor both on the pre-test and post-test, there was a major difficulty in specifically identify testosterone as being within this group of factors. In the pre-test of the athletes pointed the substance as a negative factor, with an increase with $\Delta=55 \%$ $(p$-value $=0.0017)$ in the post test. The substance is also not mentioned spontaneously as being paired with the group of anabolic steroids among bodybuilding athletes, which demonstrates a difficulty in identifying it as a negative factor even in populations living in the sport environment. ${ }^{17}$

Another substance that causes a lot of confusion is food supplements. Some contain substances such as anabolic-androgenic and psychostimulants without this being indicated on their labels, that is, there was contamination, which makes their use risky. ${ }^{18}$ In a new determination of the National Agency for Sanitary Vigilance, ${ }^{19}$ food supplements will be analysed, supervised and must meet the specific rules of composition and labelling in order to avoid fraud and contamination. In the present study, a gain of $\Delta=65 \%$ was observed in the post-test ( $p$-value $=0.0007$ ) in the aknowledgement of the danger that supplements may bring. Composing the group of supplements, we can mention the contaminated thermogenics that in the post-test there was an increase with $\Delta=35 \%$ (p-value $=0.0191)$.

In the post-test, the athletes who recognized the negative dynamics of $\mathrm{GH}$, had an increase of $\Delta=50 \%$ ( $p$-value $=0.0025$ ). This hormone called somatotrophin is related to growth and regulation of body composition by decreasing fat mass. Its abuse has been reported among high school athletes and gym users, as well as weight lifters that associate the use of $\mathrm{GH}$ with growth fator similar to insuline type 1 (IGF-1). ${ }^{20}$

On the data of the learning effectiveness about diuretics, noticed a statistically relevant gain on the subject, comparing the correct answers on the pre and post-test moments with $\Delta=25 \%$ (p-value $=0.0455$ ). This is especially important, since diuretics are among the substances classified as doping increasingly recognized and consumed by athletes for weight loss. ${ }^{21}$

\section{CONCLUSION}

The Heart in Game aimed to promote knowledge about harmful substances and regarded as doping in an innovative way, making the teaching-learning process attractive in the sports audience. In this research, it was shown that the game was an effective intervention in acquiring knowledge of the prohibited substances listed by WADA, by characterizing the negative factors, which were items that the player should avoid. This tool can contribute to science in prevention and sports education, since this game can be applied in schools, sports centers, student actions and science fairs.

All authors declare no potential conflict of interest related to this article 
AUTHORS' CONTRIBUTIONS: Each author made significant individual contributions to this manuscript. HCS (0000-0001-7806-8433)*: conception and design of the study, conducted experiments, analyzed data and interpreted results; EFM (0000-0003-4151-1213)*: edited and revised the manuscript; MCA (0000-0002-6257-5972)*: statistical analysis; FMVB (0000-0003-2669-1412)*: conducted experi-ments; RPC (0000-0003-2854-159X)*: conducted experiments; MVHB (0000-0003-1476-0054)*: conception and design of the study, critical review of content and final approval; JCCF (0000-0002-1984-9587)*: edited the manuscript; ROC (0000-0002-6333-8776)*: intellectual concept, conception and design of the study, conducted experiments, analyzed data, interpreted results, prepared the game, drafted the manuscript, editing, critical review of content and final approval. All authors approved the final version of the manuscript. *ORCID (Open Researcher and Contributor ID).

\section{REFERENCES}

1. World Anti-Doping Agency. WADA publishes 2018 list of prohibited substances and methods [internet] 2017 [access in 2018 jun 22]. Available in: https://www.wada-ama.org/en/media/news/2017-09/ wada-publishes-2018-list-of-prohibited-substances-and-methods.

2. Autoridade Brasileira de Controle de Dopagem. ABCD - Autoridade Brasileira de Controle de Dopagem [internet]. 2018 [access in 2018 sept 9]. Available in: http://www.abcd.gov.br.

3. Solimini R, Rotolo MC, Mastrobattista L, Mortali C, Minutillo A, Pichini S, et al. Hepatotoxicity associated with illicit use of anabolic androgenic steroids in doping. Eur Rev Med Pharmacol Sci. 2017;21(Suppl 1):7-16.

4. Macêdo PH, Lima MM, Santos W. Jogo digital com auxílio no estudo de matemática: um estudo de caso com estudantes do ensino fundamental I. In: Anais do Workshop de Informática na Escola. VI Congresso Brasileiro de Informática na Educação. 2017;23(1):548-57.

5. Sena S, Schmiegelow SS, Prado GM, Sousa RP, Fialho FA. Aprendizagem baseada em jogos digitais: a contribuição dos jogos epistêmicos na geração de novos conhecimentos. Rev Novas Tecnol Educ. 2016;14(1):1-11

6. De Carvalho CV. Aprendizagem baseada em jogos - Game-based learning. II World Congress on Systems Engineering and Information Technology. 2015;176-81.

7. Dias JD, Tibes CM, Fonseca LM, Zem-Mascarenhas SH. Uso de serious games para enfrentamento da obesidade infantil: revisão integrativa da literatura. Texto Contexto Enferm. 2016;26(1):1-10.

8. Oliveira MP, Gontijo DT, Monteiro RJ. Utilização de uma tecnologia educativa no processo de ensino-aprendizagem de adolescentes sobre saúde sexual e reprodutiva: relatos de experiência. In: Anais do Workshop de Informática na Escola. VI Congresso Brasileiro de Informática na Educação. 2017;23(1):118-26.

9. Fagundes AA, Lima MF, Santos CL. Jogo eletrônico como abordagem não-intrusiva e lúdica na disseminação de conhecimento em educação alimentar e nutricional infantil. Int J Knowl Engn Manage. 2016;5(13):22-41.

10. Ribeiro RJ, Silva Junior N, Frasson AC, Pilatti LA, da Silva SC. Teorias de aprendizagem em jogos digitais educacionais: um panorama brasileiro. Rev Novas Tecnol Educ. 2015;13(1):1-10.
11. Dondi C, Moretti M. A methodological proposal for learning games selection and quality assessment. Br J Educ Technol. 2007;38(3):502-12.

12. von Wangenheim CG, von Wangenheim A. Ensinando Computação com Jogos. Florianópolis: Bookess; 2012.

13. Medronho RA, Bloch KV, Luiz RR, Werneck GL. Epidemiologia. 2aa ed. São Paulo: Atheneu; 2009. 493.

14. Falcão LE. A cafeína pode ser utilizada em exercícios anaeróbicos?. Rev Bras Nutr Esportiva. 2016;10(57):335-42.

15. World Anti-Doping Agency. World anti-doping code [internet]. 2015 [access in 2018 febr 2]. Available in: https://www.wada-ama.org/sites/default/files/resources/files/wada-2015-world-anti-doping-code.pdf

16. Orr R, Grassmayr M, Macniven R, Grunseit A, Halaki M, Bauman A. Australian athletes' knowledge of the WADA Prohibited Substances List and performance enhancing substances. Int J Drug Policy. 2018;56:40-5.

17. Carneiro Júnior MA, Silva AC De Almeida MM. Nível de conhecimento e ocorrência do uso de anabolizantes entre praticantes de musculação. Rev Cient Fagoc Saude. 2016;1(1):37-40.

18. Parra RM, Palma A, Pierucci AP. Contaminação de suplementos dietéticos usados para prática esportiva: uma revisão de literatura. Rev Bras Ciênc Esporte. 2011;33(4):1071-84.

19. Agência Nacional de Vigilância Sanitária. Suplementos alimentares ganham regulamentação inédita [internet]. 2018 [access in 2018 aug 12] Available in: http://portal.anvisa.gov.br/

20. Siebert DM, Rao AL. The Use and abuse of human growth hormone in sports. Sports Health. 2018;10(5):419-26.

21. Helmlin HJ, Mürner A, Steiner S, Kamber M, Weber C, Geyer H, et al. Detection of the diuretic hydrochlorothiazide in a doping control urine sample as the result of a non-steroidal anti-inflammatory drug (NSAID) tablet contamination. Forensic Sci int. 2016;267:166-72. 